\title{
Ketercapaian Tugas-Tugas Perkembangan Remaja dan Pendidikan Seksual Pada Remaja
}

Fuaddillah Putra \& Ramdani

Universitas Negeri Padang

\section{Abstract}

Adolescence is a transitional period between childhood into adulthood, or period of a years, during which time they must meet some development tasks. Adolescent development tasks must be accomplished by a teenager. Fostering social relationships closer to same-sex and opposite sex friends is one of the nine developmental tasks that must be met by teenagers. The development task in achieving common understanding of the crisis affecting the values and morals that occurred in the community, such as the occurrence of free sex among teenagers. The occurrence of free sex for example form a misunderstanding of the meaning of fostering social connections among these teens, can be caused by a lack of sex education, information obtained by the teenagers, both from the family environment as well as from the environment outside the family (society and education in schools). Sex education is education which is given to individuals and discuss about reproductive health as well as things that can cause teens are no longer responsible for the reproductive organs. Fulfilling the development tasks that should be fulfilled by the teens must be accompanied by the guidance they can get from the people around them, thus fulfilling the development tasks can be in accordance with the values and norms that apply in an environment where they do the activity of life.

Keyword: Tugas-tugas Perkembangan Remaja, Pendidikan Seks

Copyright @ 2014 IICE - Multikarya Kons (Padang - Indonesia) dan IKI - Ikatan Konselor Indonesia - All Rights Reserved Indonesian Institute for Counseling and Education (IICE) Multikarya Kons

\section{PENDAHULUAN}

Manusia merupakan salah satu makhkuk hidup yang menjalani kehidupan di muka bumi, hal ini merupakan salah satu bentuk kehebatan Sang Pencipta. Dalam menjalani kehidupan tersebut, manusia akan menjalani kehidupan yang akan melibatkan manusia lainnya. Istilah ini dikenal dengan "manusia sebagai makhluk sosial". Dalam menjalani kehidupan manusia akan mengalami perkembangan yang dimulai semenjak mereka di dalam kandungan sampai kematian atau ajal mendatangi mereka.

Desmita (2006: 5) menjelaskan bahwa perkembangan (development) adalah serangkaian perubahan yang berlangsung secara terus-menerus dan bersifat tetap dari fungsi-fungsi jasmaniah dan rohaniah yang dimiliki oleh manusia/individu menuju ke tahap kematangan melalui pertumbuhan, pematangan, dan belajar. Selama masa kanak-kanak sampai menginjak remaja, individu akan mengalami perkembangan dalam struktur fisik dan mental, jasmaniah dan rohani sebagai ciri-ciri dalam memasuiki kedewasaan. Dalam menjalani proses perkembangan, individu akan menjalani atau memenuhi tuntutan-tuntutan yang diembankan kepada mereka yang dapat membantu dan membuat mereka diterima oleh ligkungan sosialnya. Salah satu dari tuntutan-tuntutan tersebut adalah harus 
memenuhi tugas-tugas perkembangannya. Apabila tugas-tugas berhasil diselesaikan dengan baik, maka akan tercapai kepuasan, kebahagian dan penerimaan dari lingkungan. Havighurst (dalam Ausubel, 2002: 52) menjelaskan beberapa tugas perkembangan yang harus dipenuhi oleh para remaja, antara lain:

1. Remaja mampu menerima keadaan fisik secara positif dan mampu menjalankan peran yang sesuai dengan jenis kelamin baik peran maskulin maupun peran feminim.

2. Remaja mampu membina hubungan baru dengan teman sejenis maupun teman yang berbeda jenis kelamin.

3. Remaja mampu mencapai perilaku yang bertanggung jawab secara sosial.

4. Remaja mampu mempersiapkan pernikahan dan kehidupan keluarga.

5. Remaja mampu membangun nilai-nilai yang sesuai dengan aturan-aturan yang berlaku.

Dari beberapa tugas-tugas perkembangan yang telah dipaparkan sebelumnya, terdapat perbedaan pemahaman dan tidak tercapainya tugas-tugas perkembangan yang terjadi pada para remaja, diantaranya ada remaja yang melakukan hubungan seks diluar nikah, dimana hal tersebut dapat mengakibatkan pernikahan yang terlalu dini atau adanya remaja wanita yang melakukan aborsi, selanjutnya ada remaja yang melakukan operasi plastik dikarenakan mereaka merasa kurang puas terhadap kondisi fisik yang sedang mereka alami. Divana Perdana (2011: 16) menjelaskan beberapa hasil penelitian yang menjelaskan bahwa banyak sekali terjadi perilaku seksual yang tidak bertanggung jawab yang dilakukan oleh kaum pelajar (mahasiswa), dimana banyak juga terjadi perilaku seks bebas di kalangan remaja tersebut. Selanjutnya hasil penelususran salah satu program reality show salah satu stasiun televisi terkemuka di Indonesia menemukan adanya perilaku seks bebas di kalangan siswa di salah satu Sekolah Menengah Atas di Indonesia. Perilaku tersebut dikenal dengan istilah "arisan seks", yang mana bagi namanya yang tercabut di dalam arisan maka ia mendapatkan kekuasaan kepada siapa ia akan melakukan seks bebas terhadap anggota arisan yang berbeda jenis kelamin.

Dalam menindaklanjuti kondisi tersebut, pemberian pendidikan seks pada remaja merupakan salah satu solusi dalam mengentaskan permasalahan-permasalahan yang dialami oleh para remaja saat ini. Pendidikan seks adalah mengajarkan dan memberi pengertian serta menjelaskan masalah-masalah yang menyangkut seks, naluri dan perkawinan kepada anak semenjak akalnya mulai tumbuh dan siap memahami hal-hal mengenai seks. Selanjutnya Djiwandono (dalam Elfanita, 2001: 9) juga menyatakan bahwa sesungguhnya pendidikan seks meliputi sikap, contoh pribadi dan cara hidup. Berdasarkan penjelasan di atas dapat disimpulkan bahwa pendidikan seks merupakan salah satu upaya yang dilakukan oleh individu lain terhadap individu lainya (remaja) dalam menghindari mereka terhadap perilaku yang tidak bertanggung jawab serta kebersihan dan kesehatan kondisi tubuh mereka baik dari segi fisik maupun psikologis.

Sarwono (1989:190) pendidikan seks merupakan salah satu cara untuk mengurangi atau mencegah penyalahgunaan seks, khususnya untuk mencegah dampak-dampak negatif yang tidak diharapkan seperti, kehamilan yang tidak direncanakan, penyakit menular seksual, depresi dan perasan berdosa. Penelitian Zelnik dan Kim (dalam Sarwono, 1989: 191) menerangkan bahwa remaja yang belum menikah dan belum mendapatkan pendidikan seks cenderung lebih tinggi persentasenya dalam melakukan hubungan seksual di luar nikah dibandingkan remaja yang sudah mendapatkan pendidikan seks. Pendidikan seks merupakan salah satu metode penginformasian kepada remaja yang membahas tentang masalah pertumbuhan, perkembangan fisik yang sedang dilalui oleh remaja di saat masa perkembangan. Menurut Reiss dan Halstead (2006: 274) salah satu tujuan pendidikan seks adalah membantu remaja mengetahui topik-topik biologis seperti pertumbuhan serta menimbulkan sikap emosional yang sehat dan bertanggung jawab terhadap seks.

Hal senada juga dikemukakan oleh Gerarpeat (dalam Elfanita 2008: 18), tujuan dari pendidikan seks adalah membentuk sikap emosional yang sehat terhadap masalah seksual dan membimbing para remaja ke arah hidup yang dewasa, sehat dan bertanggung jawab terhadap seksualnya agar anak dan para remaja tidak lagi 
menganggap seks tersebut sebagai sesuatu yang kotor dan menjijikkan. Di saat para remaja dan anak tidak menganggap seks tersebut sebagai sesuatu yang tabu dan menjijikkan mereka akan berani mencari informasiinformasi yang mana informasi tersebut dapat membuat mereka memahami mana saja hal-hal yang dapat merugikan diri mereka, keluarga dan masyarakat sekitar, serta mereka dapat pula menyalurkan dorongan tersebut ke arah tindakan yang lebih baik.

Di masa remaja ketika fungsi organ reproduksi dan sistem hormonal mulai bekerja, secara alamiah remaja menjadi sangat ingin tahu tentang seks. Keingintahuan mereka biasanya disalurkan lewat perbincangan dengan teman sebaya, mencari informasi dari sumber-sumber pornografi, dan mempraktekkan dengan diri sendiri, pacar, teman, atau orang lain. Fenomena di lapangan mengungkapkan prilaku seks yang memprihatinkan seperti fenomena mairil pada salah satu Sekolah Menengah Atas. Menurut Syarifuddin (2005) mairil merupakan jenis atau aktivitas pelampiasan seksual dengan kelamin sejenis yang dilakukan seseorang ketika hasrat seksualnya sedang memuncak dan merupakan perilaku kasih sayang kepada seseorang yang sejenis. Lebih lanjut Syarifuddin (2005) memaparkan bahwa Ibarat lokalisasi, pesantren sering dijadikan tempat untuk menyalurkan hasrat libido santri pada santri lain yang mana dilakukan secara sembunyi-sembunyi dan umumnya dilakukan di tengah malam ketika "korban" sedang tertidur lelap.

Fenomena lain berkaitan dengan prilaku seksual yaitu remaja dan pelajar di Gang Doli yang masih duduk di bangku sekolah dasar dan sekolah menengah pertama layaknya orang dewasa pemburu seks entah karena nafsu atau sekedar ikut-ikutan menjadi pelanggan PSK umur 60 tahun dengan bayaran sesanggupnya, bisa seribu atau dua ribu rupiah, sebagai perwujudan tercemarnya kejiwaan generasi muda yang terhubung dengan lokasi itu.

Berdasarkan beberapa fenomena yang diungkapkan di atas, dapat diketahui bahwa remaja dalam tahap perkembangannya terutama dalam menjalin hubungan sosial memiliki keterkaitan yang erat terhadap prilaku seksualitas dan diperlukan perhatian khusus guna mengontrol prilaku tersebut.

Hasil penelitian yang dilakukan oleh Fuaddillah Putra (2012) mengungkapkan bahwa pemberian pendidikan seks yang diberikan oleh guru BK terhadap para siswa Sekolah Menengah Atas memiliki dampak yang positif terhadap pemahaman mereka terhadap pendidikan seks. Hal ini terlihat dari 87.3\% siswa menyatakan bahwa dengan pemberian pendidikan seks dapat membantu mereka dalam berperilaku dan bersikap yang tepat dengan teman sejenis maupun berbeda jenis kelamin di lingkungan masyarakat. Selanjutnya hasil penelitian Fuaddillah Putra (2013) menyimpulkan bahwa terdapat perbedaan yang signifikan antara siswa SMA X dan Pondok Pesantren Y, yang mana pada Pondok Pesantren adanya pelarangan terjadinya interaksi sosial antara siswa berbeda jenis kelamin, sehingga mengakibatkan ketercapaian tugas-tugas perkembangan siswa di Pondok Pesantren lebih rendah dibandingkan siswa yang berada di SMA.

Pendidikan seks di sekolah dapat memberikan peran penting dalam hal peningkatan pengetahuan, tingkah laku dan sikap yang sesuai bagi para remaja. Selain itu peran masyarakat secara luas juga diperlukan supaya tercipta iklim pemberian informasi terutama mengenai pendidikan seks yang tepat dan sesuai untuk remaja. Muhammad Nur Abdul Hafizh (1995) mengemukakan bahwa materi pendidikan seks yang dapat diberikan kepada remaja antara lain sebagai berikut :

1. Membiasakan anak menundukkan pandangan mata dan menutup aurat.

2. Membiasakan anak untuk meminta izin ketika masuk ke kamar orang tua.

3. Memisahkan tempat tidur anak dengan saudaranya yang berbeda jenis kelamin.

4. Larangan tidur bertelungkup.

5. Menjauhkan anak dari perbuatan zina

Selanjutnya, Sinta Ratna Dewi (1998) memaparkan materi yang dapat diberikan dalam pelaksanaaan pendidikan seks yaitu : 
1. Perkembangan seksualitas manusia, termasuk keragaman seksual

2. kesehatan reproduksi (anatomi sistem reproduksi, fisiologi, aborsi, kontrasepsi, AIDS/PMS, perawatan ibu-bayi, kekerasan seksual, perilaku reproduksi)

3. perilaku seksual

4. kemampuan personal: mempertimbangkan nilai, mengambil keputusan, mengkomunikasikan pendapat dan perasaan, beregosiasi

5. Faktor agama, sos-bud (terrnasuk gender) dalam masalah seksualitas

6. Hubungan antar manusia meliputi: hubungan dengan orangtua, pacaran, dll

Lebih lanjut dipaparkan beberapa poin-poin dari topik / materi penting yang secara umum perlu diketahui anak, yang perlu disampaikan dalam sex education : (diunduh dari Edukasi Seks Sejak Dini), yaitu :

1. Mengenalkan Perbedaan lawan Jenis

Jelaskan bahwa Tuhan menciptakan laki-laki dan perempuan yang memiliki perbedaan jenis kelamin. Hal ini yang menyebabkan beberapa hal menjadi berbeda, seperti cara berpakaian, gaya rambut, cara buang air kecil. Terangkan bahwa anak laki-laki jika sudah besar akan jadi ayah dan anak perempuan akan menjadi ibu. Tugas utama ayah adalah mencari nafkah, walaupun harus tetap memperhatikan keluarga. Adapun tugas utama ibu adalah mengatur rumah tangga dan keluarga. Namun, tidak menutup kemungkinan seorang ibu membantu ayah dalam mencukupi kebutuhan. Dengan demikian, anak bisa memahami peran jenis kelamin dengan baik dan benar.

2. Memperkenalkan Organ Seks

Caranya cukup mudah, misalnya dengan menggunakan boneka ataupun ketika mandi. Perkenalkan anak secara singkat organ tubuh yang dimiliki, seperti rambut, kepala, tangan, kaki, perut, serta jangan lupa penis dan vagina. Terangkan juga fungsi dari anggota tubuh dan cara pemeliharaannya agar terhindar dari kuman penyakit.

3. Menghindari Anak Dari Kemungkinan Pelecehan Seksual

Tegaskan pada anak bahwa alat kelamin tidak boleh dipertontonkan secara sembarangan. Tumbuhkan rasa malu pada anak, misalnya ketiika keluar dari kamar mandi hendaknya mengenakan pakaian atau handuk penutup. Selain itu, jika ada yang menyentuhnya, segera laporkan pada orang tua atau guru di sekolah. Anak boleh teriak sekeras-kerasnya dalam hal ini untuk melindungi dirinya.

4. Informasikan Tentang Asal-Usul Anak

Untuk anak usia prasekolah, bisa diterangkan bahwa anak berasal dari perut ibu, misalnya sambil menunjuk perut ibu atau pada ibu yang sedang hamil. Sejalan dengan usia, anak boleh diterangkan bahwa seorang anak berasal dari sel telur ibu yang dibuahi oleh sperma yang berasal dari ayah. Tekankan bahwa pembuahan boleh atau bisa dilakukan setelah wanita dan pria menikah.

5. Persiapan Menghadapi Masa Pubertas

Informasikan bahwa seiring bertambahnya usia, anak akan mengalami perubahan dan perkembangan. Perubahan yang jelas terlihat adalah ketika memasuki masa pubertas. Anak perempuan akan mengalami menstruasi/haid, sedangkan anak laki-laki mengalami mimpi basah. Hal ini menandai juga perubahan pada bentuk tubuh dan kualitas, misalnya bagian dada yang membesar pada wanita dan suara yang memberat pada seorang pria. 
Materi pendidikan seks hendaknya disesuaikan dengan kebutuhan dan tahap perkembangan anak. Masalah materi pendidikan seks memang tidak mudah, bahkan sulit sekali menangkap secara kongkrit. Pernah sebuah buku mencoba menjelaskan tentang hal-hal yang berhubungan dengan seks dilengkapi dengan gambargambar organ tubuh manusia ditarik dari peredaran karena dianggap akan merusak mental kaum muda

\section{PENUTUP}

pemberian pendidikan seks kepada remaja dapat membantu mereka dalam menghindari perilaku seksual yang tidak sesuai dengan norma-norma dan nilai-nilai yang berlaku di masyarakat. Selanjutnya dengan pemberian pendidikan seks pada remaja juga dapat menghindari mereka dalam salah memahami tugas-tugas perkembangan yang harus mereka penuhi, salah satunya adalah mampu membina hubungan yang lebih dekat dengan teman sejenis dan lawan jenis, dalam tugas-tugas perkembangan tersebut para remaja diminta untuk membina hubungan yang lebih dekat dengan teman sejenis dan lawan jenis dengan arti bahwa mereka hanya mengenali dan memahami karakteristik-karakteristik dari lawan jenisnya di saat mengelami pertumbuhan dan perkembangan pada masa remaja.

\section{DAFTAR PUSTAKA}

Ausubel, D. P. (2002). Theory and Problems of Adolescent Development (3 rd. ed). Lincoln: Universe.

Desmita. (2008). Psikologi Perkembangan. Bandung: PT Remaja Rosdakarya

Divana Perdana. (2011). Dugem “Ekspresi Cinta Seks dan Jati Diri. Jogjakarta: Laksana

Elfanita. (2008). Pendapat Orang Tua Tentang Pendidikan Seks Pada Remaja Dalam Keluarga. Skripsi.Padang: FIP UNP

Fuaddillah Putra. (2012). Pendapat Siswa terhadap Pendidikan Seks yang Diberikan oleh Guru BK. FIP UNP. Skripsi. Tidak Diterbitkan. FIP UNP.

Fuaddillah Putra. (2013). Perbedaan Ketercapaian Tugas-Tugas Perkembangan Siswa SMA dan Siswa Pondok Pesantren. FIP UNP. Tesis. Tidak Diterbitkan. FIP UNP.

Nur Abdul Hafizh. (1995). Mendidik Anak Bersama Rasulullah. Bandung : Al Bayan.

Reis \& Halstead. (2006). Pendidikan seks. Yogyakarta: Alenia Pers

Ruang liputan Media. (2014). Edukasi Seks Sejak Dini. Dipublikasikan online: (http://www.frisianflag.com/id/ruang-media/liputan-media/4670-edukasi-seks-sejak-dinfi)

Sarwono, Sarlito, Wirawan. (1987). Psikologi Remaja. Jakarta: Raja Grafindo

Sinta Ratna Dewi . (1998). Manager Proyek Sahabat Remaja PKBI DIY. Dipublikasikan online: (www. diskusi terbatas Pendidikan seks untuk remaja, diakses 27 Februari 2014)

Syarifuddin. (2005). Sepenggal Kisah Biru di Pesantren. Jogjakarta: P.Idea. 